\section{PENDEKATAN PERSPEKTIF WEBER TERHADAP TINDAKAN RASIONALISME PEMBUATAN PERAHU PINISI}

\author{
Diah Retno Dwi Hastuti ${ }^{*}$ \\ Mardia $^{2}$ \\ Dewi Marwati Nuryanti ${ }^{3}$ \\ Muhammad Saleh Ali ${ }^{4}$ \\ Eymal B. Demmalino 4 \\ Rahmadanih $^{4}$ \\ ${ }^{1}$ Fakultas Ekonomi Universitas Negeri Makassar \\ ${ }^{2}$ Fakultas Ekonomi Universitas Indonesia Timur \\ 3 Fakultas Pertanian, Universitas Andi Djemma \\ ${ }^{4}$ Fakultas Pertanian Universitas Hasanuddin \\ *Email: diah.retno@unm.ac.id
}

Abstrak. Kejayaan kemaritiman Indonesia dari sejarah hingga tertuang dalam sebuah syair lagu bukanlah hal yang diragukan, terutama kehandalannya dalam membuat perahu Pinisi yang prosesnya sarat dengan kearifan lokal dan nilai-nilai budaya yang tercermin dalam kehidupan sehari-hari. Penelitian yang dilakukan di Desa Bira Kecamatan Bontobahari Kabupaten Bulukumba selama Mei 2018 bertujuan mengkaji rasionalisme pembuatan perahu pinisi dengan pendekatan perspektif Weber. Tujuan tersebut menggunakan metode kualitatif dengan Pendekatan Weber dalam perspektif verstehen. Hasil temuan menunjukkan bahwa pembuatan perahu Pinisi ini masih bermuatan nuansa mistis religi mulai dari penentuan hari pembuatan sampai peluncurannya di laut walaupun unsur modernisasi mulai masuk untuk mengefisienkan waktu dan mengefektifkan biaya sebagai bentuk rasionalitas dalam bertindak, seperti dalam perspektif Weber, yaitu tindakan rasionalitas instrumental, rasionalitas nilai, tindakan afektif, dan tindakan tradisional.

Kata Kunci: tindakan rasionalitas, perspektif Weber, dan perahu pinisi
INDONESIAN JOURNAL OF FUNDAMENTAL SCIENCES (IJFS)

\section{E-ISSN: 2621-6728 \\ P-ISSN: 2621-671x}

Submitted: February $1^{\text {st }}, 2018$

Accepted : March 10 ${ }^{\text {th }}, 2018$

Abstract. Indonesia's maritime triumph from history to being written in a song lyric is not a question, especially its reliability in making Pinisi boats whose processes are full of local wisdom and cultural values reflected in everyday life. The research conducted in Bira Village, Bontobahari Sub-district, Bulukumba District in May 2018 aims to examine the rationalism of making pinisi boats with Weber's perspective approach. The aim is to use qualitative methods with Weber's approach in the verstehen perspective. The findings show that the making of the Pinisi boat is still filled with mystical nuances of religion ranging from the determination of the day of manufacture to its launch in the sea even though the elements of modernization began to come in to streamline time and streamline costs as a form of rationality in acting, as in Weber's perspective, zwerk rational, werk rational, affectual action, and traditional actions 


\section{PENDAHULUAN}

Cuplikan lagu karya Ibu Sud, yaitu “... nenek moyangku orang pelaut, gemar mengarung luas samudra, menerjang ombak tiada takut, menempuh badai sudah biasa..." (Purnomo, 2013) bukan tanpa alasan karena Indonesia memang negara kepulauan dengan luas lautan sebesar $3.273 .810 \mathrm{~km}^{2}$ dari total wilayah Indonesia, $5.193 .250 \mathrm{~km}^{2}$ (www.invonesia.com). Selanjutnya catatan sejarah pun Indonesia telah menunjukkan kekuatan maritimnya pada jaman Sriwijaya (Utomo, 2008), Majapahit (Pradhani, 2017; Wahyu, 2017), Singosari, dan Demak (Purnomo, 2013) sehingga citacita Presiden Republik Indonesia (Jokowi Widodo) untuk menjadikan Indonesia sebagai Poros Maritim Dunia (Puryono, 2016; Wahyu, 2017), terlebih hal tersebut tercermin dari semboyan Tentara Nasional Indonesia, Jalesveva Jayamahe (Rompas, 2011), bukan sekedar isapan jempol belaka. Bahkan pengakuan dunia internasional yang menyatakan Indonesia sebagai Negara Maritim telah di tetapkan dalam United Nations Convention on the Law of the Sea (UNCLOS) 1982 (Wijoyo, 2014).

Julukan sebagai bangsa pelaut juga patut diberikan kepada masyarakat BugisMakassar di Sulawesi Selatan (Lisbijanto, 2013), khususnya masyarakat Ara, Tanjung Bira, dan Lemo-Lemo (Abbas, 2011), yang sangat intim kehidupannya dengan perahu dan laut (Amar, 2013) sebagai pelaut pedagang (Saenong, 2013) atau oleh pasompe (Anwar, 2012) dengan prinsip yang telah mendarah daging, “Kula'birangngangi Tallang Na Towakna", yang mempunyai arti lebih baik tenggelam daripada surut kembali sebelum tujuan tercapai (Hakim, 1996). Kehandalannya dalam mengarungi lautan sudah tercatat dalam sejarah, seperti saat kejayaan Kerajaan Gowa sampai Srilangka, Philipina, Kamboja, Pantai Australia Utara bahkan Madagaskar (Amar, 2013) dan Afrika (Anwar, 2012) untuk berdagang (Saenong, 2013) maupun keperluan magis religius (Sukendar, 1999). Pelayaran tersebut dilakukan dengan perahu pinisi (Kurniasari et al., 2013) yang dibuat secara tradisional oleh panrita lopi (Amar, 2013; Kurniasari et al., 2013) melalui pertukaran pengalaman dari generasi tua kepada generasi muda maupun dalam satu generasi yang sama (Amir, 2016).

Dalam proses pembuatannya, mulai dari penentuan hari baik sampai peluncuran Pinisi ke laut, mengandung nilai-nilai kearifan lokal (Riyanto, 2014) atau nilai-nilai budaya (www.kemlu.go.id) yang dapat dijadikan sebagai acuan dalam kehidupan sehari-hari (Mulyadi, 2016). Nilai-nilai itu, antara lain kerjasama atau gotong-royong, kerja keras, ketelitian, keindahan, dan religius yang dilakukan secara turun-temurun (Amar, 2013). Di dalamnya terdapat perpaduan nilai-nilai dan norma yang diperkuat keyakinan serta perilakunya yang senantiasa menyatu dengan alam serta memiliki pengetahuan, tata cara, nilai, dan norma yang menjadi dasar rasionalitas dalam bertindak (Anwar, 2012).

Seiring dengan perjalanan waktu, pembuatannya mulai memasukkan unsur modern ke dalamnya, bahkan berkembang menjadi bagian industri pedesaan (Amar, 2013) yang telah diakui dunia (Kurniasari et al., 2013), akan tetapi, tetap mengedepankan ritual adat istiadat (Amar, 2013) di setiap tahapnya sebagai bentuk adaptasi dengan alam (Melalatoa, 1995; Kurniasari et al., 2013) maupun lingkungan sosialnya (Sani, 2013). Berdasarkan fenomena-fenomena tersebut, maka kajian dari tindakan rasionalitas pembuatan perahu pinisi ditinjau dari perspektif Weber menarik untuk dikaji. 


\section{METODE PENELITIAN}

Penelitian ini dilaksanakan di Desa Bira Kecamatan Bontobahari Kabupaten Bulukumba Provinsi Sulawesi Selatan (Gambar 1) selama Mei 2018. Teknik pengambilan sampel dilakukan dengan purposive sampling baik sampel wilayah maupun sampel responden. Sampel wilayah diambil karena sebagai tempat pembuatan perahu pinisi yang hanya ada di Propinsi Sulawesi Selatan bahkan di dunia, sedangkan sampel responden berupa informan kunci terdiri dari pemilik perusahaan sebanyak satu orang, panrita lopi (pembuat pinisi) sebanyak satu orang, punggawa dan sawi sebanyak enam orang, serta Kepala Desa Bira Kabupaten Bulukumba. Selanjutnya teknik pengumpulan data dilakukan wawancara mendalam (Endraswara, 2006) dan observasi (Hariwijaya, 2017). Wawancara mendalam dilakukan dengan informan kunci (Mikkelsen, 2011) sedangkan observasi dimaksudkan untuk melengkapi informasi dari hasil wawancara mendalam.

Berdasarkan sumber data berupa data primer yang diperoleh dari catatan lapang (field note) hasil wawancara dengan informan (Manzilati, 2017) dan hasil observasi selama melaksanakan survei. Data sekunder diperoleh dari hasil penelitian kepustakaan (library research) (Simanjuntak dan Sosrodihardjo, 2014), jurnal, dan hasil penelitian sebelumnya. Selanjutnya data dianalisis dengan metode kualitatif (Yusuf, 2014) dengan perspektif Verstehen (Pemahaman) sebagai alat analisis di level makro (Ritzer, 2012; Ritzer dan Goodman. 2008).

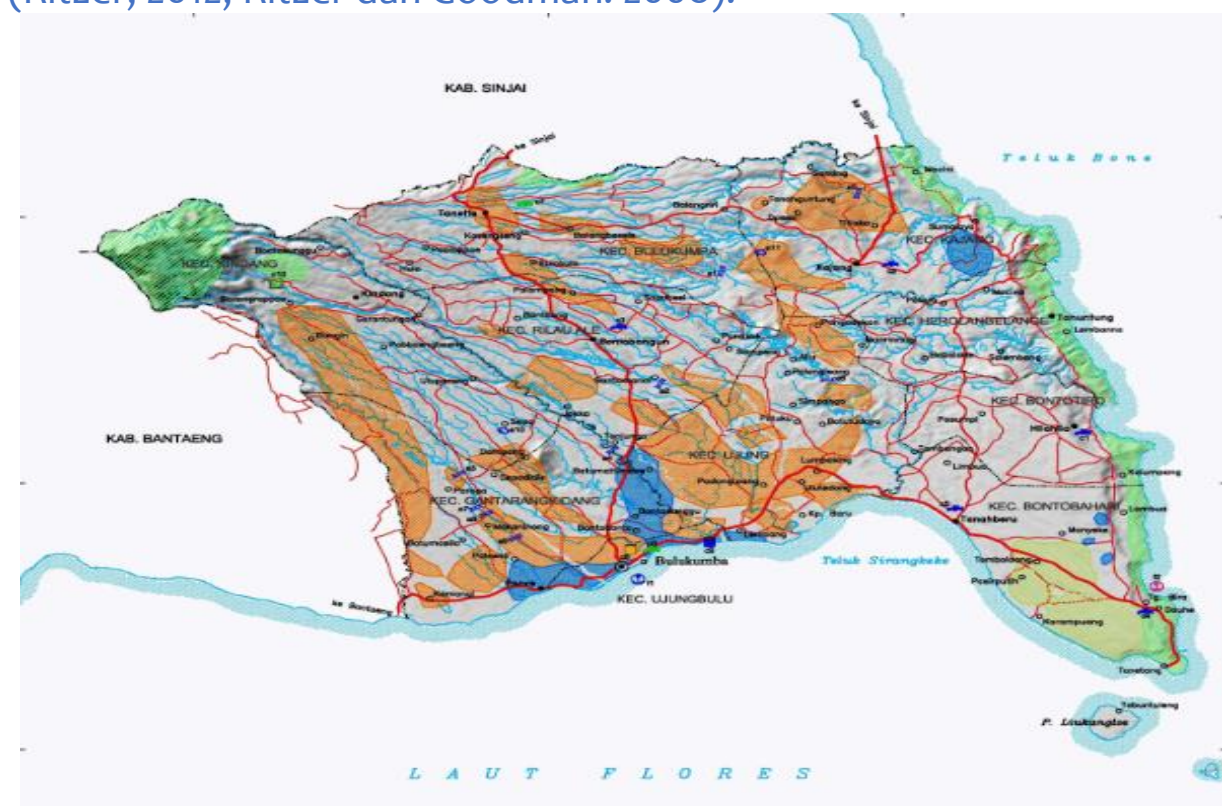

Gambar 1. Peta Kabupaten Bulukumba Provinsi Sulawesi Selatan Sumber: Kementerian Pekerjaan Umum dan Perumahan Rakyat (2016)

\section{HASIL DAN PEMBAHASAN}

Pinisi adalah sebuah nama kapal/ perahu layar yang menggunakan jenis layar sekunar dengan dua tiang dan tujuh helai layar yang mempunyai makna bahwa nenek moyang bangsa Indonesia mampu mengarungi tujuh samudera besar di dunia dan berasal dari Suku Bugis dan Suku Makassar di Sulawesi Selatan tepatnya dari Desa 
Bira Kecamatan Bonto Bahari Kabupaten Bulukumba (Ahmad, 2017). Pinisi sebenarnya merupakan nama layar. Dua tiang layar utama tersebut berdasarkan 2 kalimat syahadat dan tujuh buah layar merupakan jumlah dari surah Al-Fatihah (Ahmad, 2017).

Perahu Pinisi termasuk alat transportasi laut tradisional masyarakat BugisMakassar yang terkenal sejak berabad-abad yang lalu dan terdapat dalam naskah Lontarak I Babad La Lagaligo sekitar abad ke-14 Masehi (Ahmad, 2017). Selanjutnya menurut Ahmad (2017) Perahu Pinisi Nusantara telah berhasil berlayar ke Vancouver Kanada, Amerika Serikat pada Tahun 1986. Oleh karena itu, Bulukumba dijuluki sebagai Butta Panritta Lopi (Kurniasari et al., 2013), yang artinya tanah para ahli pembuat perahu pinisi. Pusat kerajinan Perahu Pinisi ini terletak di pesisir Pantai Bira, Kecamatan Bontobahari, sekitar 24 km dari kota Kabupaten Bulukumba. Pusat kerajinan membuat para turis dapat melihat kapal-kapal pinisi yang sedang dalam proses pembuatannya dengan metode alat-alat tradisional dan modern.

Selain cara dan peralatannya secara tradisional, pembuatan kapal pinisi di Desa Bira mengikuti ritual-ritual yang sudah dilakukan sejak zaman dahulu, dimulai menentukan hari baik untuk mencari bahan baku, menebang, mengolah batang pohon menjadi bahan baku, merakit bahan baku menjadi perahu, dan meluncurkan perahu ke laut merupakan prosesi adat itu dengan sebutan "Ruling" (Wijoyo, 2014). Prosesi ini lahir karena masyarakat Bira Kecamatan Bontobahari Kabupaten Bulukumba yang berprofesi sebagai pembuat perahu. Menurut Kurniasari et al., (2013) dan Haryati (2017) prosesi tersebut menganggap dirinya beserta komunitasnya sebagai bahagian dari jagad raya, ibaratnya mereka adalah mikrokosmos dan jagad raya adalah makrokosmos. Hubungan kedua kosmos ini diatur oleh peraturan abadi yang sakral, dan dilembagakan oleh para leluhur mereka sebagai adat istiadat yang wajib dijaga keutuhannya sangat kental di pengaruhi oleh Mitos Sawerigading (Kurniasari et al., 2013).

Makrokosmos dalam pengertian luasnya yang berarti suatu susunan keseluruhan atau kompleks yang dipandang dalam totalitasnya atau sebagai suatu keseluruhan yang aktif serta terstruktur atau alam semesta sebagai sebuah keseluruhan atau sistem yang terpadu dan tunggal (Haryati, 2017). Lawan dari makrokosmos adalah mikrokosmos yaitu bagian kecil dari satu keseluruhan (Asy'ari, 1999). Mikrokosmos dan makrokosmos disebut juga kosmonologi. Kosmologi merupakan cabang filsafat yang disebut juga filsafat fisika atau filsafat alam (Haryati, 2017). Kosmologi membahas hakikat alam semesta, menyingkap eksistensinya yang tersembunyi di balik penampakan fisik (Asy’ari, 1999; Haryati, 2017), sebuah refleksi holistik dan mendalam untuk mempertanyakan ha-hal yang berada di balik alam semesta (alam fisik/empiris). Selanjutnya kosmologi (Kattsoff, 1996; Haryati, 2017) memberi penekanan pada beberapa hal, yaitu kajian filsafat tentang istilah-istilah pokok yang terdapat dalam fisika seperti ruang dan waktu, Pra-anggapan yang terdapat dalam fisika sebagai ilmu tentang jagad raya, serta filsafat fisika yaitu berupa penyelidikan mengenai susunan ilmu fisika sebagai ilmu, dan analisa terhadap metode-metode yang digunakannya. Ruang lingkup tersebut menunjukkan bahwa kosmologi mengkaji masalah-masalah mengenai fisika, bukan masalah-masalah dalam fisika. 
Jadi kosmologi memperoleh pengertian yang lebih jelas dalam pembahasan tentang eksistensi Yang Esa sebagai alam semesta, kenyataan mendasar makrokosmos yang menempatkan manusia dalam posisinya sebagai mikrokosmos, dan berimplikasi pada perilaku etis yang seharusnya dilakukannya di alam semesta (Haryati, 2017). Prosesi ritual Ruling dipimpin oleh tokoh adat yang juga ahli membuat kapal/perahu disebut Panrita Lopi, sedangkan untuk pelaksana teknis dan fisik pembuatannya dipimpin oleh Kepala Tukang yang biasa disebut Punggawa, dibantu oleh tukang atau disebut Sawi serta calon Sawi (Kurniasari et al., 2013). Punggawa dan Sawi inilah yang bekerja menyelesaikan sebuah kapal/perahu phinisi dengan berbagai macam ukuran dan grosstonase (Ahmad, 2017). Tidak seperti pembuatan kapal pada umumnya, rangka kapal dibuat terlebih dahulu kemudian menyusul pembuatan dindingnya, kapal/perahu pinisi memiliki keunikan tersendiri dalam pembuatannya, yaitu pembuatannya dimulai dengan pembuatan dinding kapal, baru setelah itu dilanjutkan dengan pembuatan rangka kapal. Rangka dibuat menyesuaikan dengan dinding perahu.

Pembuatan kapal/perahu Pinisi adalah kombinasi dari pengetahuan dan pengalaman tradisional warisan leluhur yang harus diikuti untuk memastikan keamanan di laut, seperti penghitungan hari baik untuk memulai pencarian kayu sebagai bahan baku atau untuk memulai langsung membangun perahu (Ahmad, 2017). Hitungan itu biasa jatuh di hari ke-5 (lima) atau ke-7 (tujuh) pada bulan yang berjalan. Angka 5 atau naparilimai dalle'na yang bermakna rezeki sudah di tangan, dan angka 7 atau natujuangngi dalle'na memiliki makna selalu mendapatkan rezeki (Ahmad, 2017).

Pembuatan kapal pinisi memakan waktu 3 sampai 6 bulan. Hal tersebut bergantung kesiapan bahan dan musim dengan harga sebuah perahu juga bermacam-macam sesuai ukuran dan kesepakatan. Sistem pembayaran pembuatan sebuah perahu sendiri bisa secara tunai, namun biasanya dilakukan pembayaran 3 (tiga) kali, tergantung pada kesepakatan. Biasanya ada uang muka $30 \%$, sisanya $20 \%$ setelah perahu selesai (Ahmad, 2017). Berdasarkan jenisnya, kapal/perahu yang dibuat sebagai kapal penumpang atau kargo disebut pinisi modern yang sudah dilengkapi dengan mesin motor diesel sebagai penggerak utamanya. Menurut (Ahmad, 2017) perahu yang dimaksud adalah perahu langsung motor (PLM) yang kebanyakan dipakai sebagai alat transportasi pariwisata bahkan menjadi kapal motor (KM) yang kebanyakan dipakai langsung sebagai alat transportasi barang (Cargo), serta ukuran yang lebih kecil dari jenis Lambo disebut Palari.

Selain perahu/kapal penumpang dan kargo, ada juga jenis yang lebih kecil, yaitu Perahu Pajala dan Perahu Jolloro, yaitu perahu nelayan yang digunakan untuk menangkap ikan, disamping itu ada juga perahu tanpa lunas yang disebut Lepa-lepa, Soppe, dan Jarangka versi besar dikenal sebagai Perahu/Kapal Padewakang, yaitu kapal/perahu kuno pertama dimana dindingnya terdiri dari kepingan-kepingan papan yang tersusun, selanjut ada juga kapal/perahu kuno yang disebut Patorani (Ahmad, 2017) dan perahu buatan masyarakat Bira sangat diminati di Manca Negara, terutama dari negara Eropa, seperti Spanyol, Jerman, Perancis dan Belanda, juga dari Jepang, Amerika, Afrika, Kanada, Singapura dan Malaysia serta tentunya dari Indonesia. 
Jika dihubungkan dengan rasionalitas pembuatan kapal/perahu pinisi, maka kajian ini menggunakan pendekatan Weber dengan perspektif Verstehen. Menurut Ritzer (2012) dan Hastuti, et al., (2018) bahwa definisi rasionalitas pada karya Weber sangat sulit dirumuskan akibat pendefinisian yang berbeda dalam diskusinya sehingga dibedakan menjadi dua jenis rasionalitas, yaitu rasionalitas alat-tujuan dan rasionalitas nilai (Ritzer, 2012). Selanjutnya atas dasar rasionalitas, Weber kembali membedakan tindakan sosial manusia ke dalam 4 (empat) tipe karena semakin rasional tindakan sosial itu semakin mudah dipahami, yaitu (a) tindakan rasionalitas instrumental (zwerk rational), (b) tindakan rasionalitas nilai (werk rational), (c) tindakan afektif/ tindakan yang dipengaruhi emosi (affectual Action), dan (d) tindakan tradisional/ tindakan karena kebiasaan (traditional action) (Ritzer, 2012).

Tindakan rasionalitas instrumental dengan mengandalkan alat tradisional merupakan suatu tindakan sosial yang dilakukan seseorang didasarkan atas pertimbangan dan pilihan sadar yang berhubungan dengan tujuan tindakan itu dan ketersediaan alat yang dipergunakan untuk mencapainya, dengan perkataan lain menilai dan menentukan tujuan itu dan bisa saja tindakan itu dijadikan sebagai cara untuk mencapai tujuan lain (Ritzer, 2012; Hastuti, et al., 2018). Pada kasus ini peralatan modern telah mendominasi proses pembuatan perahu oleh punggawa dan sawi di Desa Bira Kecamatan Bontobahari Kabupaten Bulukumba untuk mempercepat pesanan konsumen yang sebelumnya telah menggunakan peralatan tradisional, misalnya alat penghalus kayu dan penarik kapal ke laut.

Selanjutnya tindakan rasionalitas nilai, tindakan ini memiliki sifat bahwa alatalat yang ada hanya merupakan pertimbangan dan perhitungan yang sadar, sementara tujuan tujuannya sudah ada di dalam hubungannya dengan nilai-nilai individu yang bersifat absolut. Artinya, tindakan sosial ini telah dipertimbangkan terlebih dahulu karena mendahulukan nilai-nilai sosial maupun nilai agama yang ia miliki (Ritzer, 2012) dengan melibatkan orang-orang dalam mengkoordinir secara mikrokosmos dan makrokosmos. (Ritzer, 2012; Hastuti, et al., 2018). Dengan menjaga alam untuk kesinambungan pekerjaannya. Langkah ini diambil dengan mengambil bahan baku kayu yang bersertifikat dari Sulawesi Tengah, menggantikan dari Kecamatan Kajang, karena jika kayu habis, maka para pekerja dapat kehilangan pekerjaan. Hubungan antara manusia dan alam telah tertuang pula antar panrita lopi, punggawa, dan sawi di Desa Bira dalam pembuatan perahu pinisi dengan melihat kondisi alam untuk memastikan keamanan dengan hitungan angka harian ke- 5 atau ke-7 pada bulan berjalan yang memiliki makna untuk mendapatkan rejeki yang baik.

Lain halnya tindakan afektif/ tindakan yang dipengaruhi emosi, tipe tindakan sosial ini lebih didominasi perasaan atau emosi tanpa refleksi intelektual atau perencanaan sadar (Ritzer, 2012). Tindakan afektif sifatnya spontan, tidak rasional, dan merupakan ekspresi emosional dari individu. Tindakan ini biasanya terjadi atas rangsangan dari luar yang bersifat otomatis. Punggawa dan sawi menerima pekerjaan dari panrita lopi dalam membuat perahu pinisi karena kebutuhan uang mendesak sehingga tidak memikirkan waktu bersama keluarganya. Hal tersebut terlihat dari pembuatan perahu yang bersifat borongan pun ada yang meninggalkan studinya untuk bekerja. Sedangkan tindakan tradisional/ tindakan karena kebiasaan, dalam tindakan jenis ini seseorang memperlihatkan perilaku tertentu karena kebiasaan yang 
diperoleh dari nenek moyang, tanpa refleksi yang sadar atau perencanaan (Ritzer, 2012; Hastuti, et al., 2018). Pekerjaan dalam membuat perahu pinisi terkadang dilakukan oleh Punggawa dan Sawi tanpa melihat sketsa gambar perahu karena kebiasaan dan turun-temurun dari orang tuanya.

Dari keempat tindakan tersebut, tentunya erat kaitannya dalam keseharian masyarakat Desa Bira hingga saat ini seperti upacara adat pembuatan perahu Pinisi yang cukup unik, karena proses pembuatannya memadukan keterampilan teknis dengan kekuatan magis yang dikenal dengan prosesi Ruling yang lahir karena masyarakat Bira menganggap dirinya sebagai mikrokosmos sebagai bahagian jagad raya dan makrokosmos sebagai jagad raya yang telah dijelaskan sebelumnya. Selain itu terdapat rasionalitas tujuan yang mengandalkan keahlian pembuat perahu untuk membuat perahu sesuai pesanan. Misalnya perahu layar motor untuk wisata dan perahu/kapal motor untuk dagang atau kargo.

\section{KESIMPULAN}

Tindakan rasionalitas pembuatan kapal/ perahu Pinisi oleh masyarakat Desa Bira Kecamatan Bontobahari Kabupaten Bulukumba Provinsi Sulawesi Selatan dapat dilakukan dengan pendekatan Weber dalam perspektif Verstehen terdiri dari Tindakan rasionalitas instrumental, tindakan rasionalitas nilai, tindakan afektif, dan tindakan tradisional dengan melibatkan orang-orang dalam mengkoordinir secara mikrokosmos dan makrokosmos. Tindakan tersebut dilakukan melalui proses ritual disebut Ruling yang dipimpin oleh tokoh adat yang juga ahli membuat kapal/perahu disebut panrita lopi, sedangkan untuk pelaksana teknis dan fisik pembuatannya dipimpin oleh Kepala Tukang yang biasa disebut punggawa, dibantu oleh tukang atau disebut Sawi.

\section{DAFTAR PUSTAKA}

Abbas. (2001). Pinisi Perahu Khas Sulawesi Selatan. Makassar: Dinas Kebudayaan dan Pariwisata Provinsi Sulawesi Selatan

Ahmad. (2017). Mengenal Makna Ilahiah, Dua Tiang Tujuh Layar Perahu Phinisi Bulukumba. Parinta News. https://panrita.news/2017/10/18/mengenal-maknailahiah-dua-tiang-tujuh-layar-perahu-phinisi-bulukumba/

Amar, S. (2013). Asal Usul dan Keahlian Pembuatan Perahu Pinisi di Tanah Lemo Bulukumba (Tinjauan dalam Berbagai Versi). Jurnal Education. 8(2): 151-160

Amir, R. (2016). Transformasi Budaya dalam Perspektif Pendidikan Non Formal (Studi pada Masyarakat Pembuat Kapal Phinisi di Kabupaten Bulukumba). Jurnal Penelitian Humano. 7(1): 46-63

Anwar, S. J. (2012). Pengetahuan Lokal (Indigenous Knowledge) "Pasompe" BugisMakassar dalam Menjelajah Nusantara. Sosiologi Reflektif. 7(1): 65-77

Asy'ari, M. (1999). Filsafat Islam Sunnah Nabi dalam Berpikir. LESFI. Yogyakarta

Endraswara, S. (2006). Metode, Teori, Teknik Penelitian Kebudayaan. Pustaka Widyatama. Jogjakarta

Hakim, B. (1996). Hubungan Antara Sulawesi dan Jawa Studi Jalur Pelayaran Perdagangan Kuno Abad XVII M. Bandung: Jendral Kebudayaan 
Haryati, T.A. (2017). Kosmologi Jawa Sebagai Landasan Filosofis Etika Lingkungan. Religia. 20(2):174-189

Hariwijaya, M. (2017). Metodologi dan Teknik Penulisan Skripsi, Tesis dan Disertasi: untuk Ilmu-ilmu Sosial dan Humoniora. Diandra Kreatif. Jogjakarta

Hastuti, D.R.D., M. S. Ali, E. B. Demmallino, dan Rahmadanih. (2018). Ringkasan Kumpulan Mazhab Teori Sosial (Biografi, Sejarah, Teori, dan Kritikan). Pustaka Taman Ilmu. Makassar

Kattsoff, Louis O. (1992). Pengantar Filsafat (diterjemahkan oleh Soejono Soemargono). Tiara Wacana. Yogyakarta

Kementerian Pekerjaan Umum dan Perumahan Rakyat. (2016). Peta Infrastruktur Kabupaten Bulukumba. loketpeta.pu.go.id diakses 30 Mei 2018

Kurniasari, N., C. Yuliaty, dan Nurlaili. (2013). Dimensi Religi dalam Pembuatan Pinisi. Jurnal Sosial Ekonomi Kelautan dan Perikanan. 8(1): 75-83

Lisbijanto, H. (2013). Kapal Pinisi. Graha Ilmu. Jogjakarta

Manzilati, A. (2017). Metodologi Penelitian Kualitatif: Paradigma, Metode, dan Aplikasi. Universitas Brawijaya Press. Malang

Melalatoa, M. J. (1995). Ensiklopedi Suku Bangsa di Indonesia Volume 1. Departemen Pendidikan dan Kebudayaan Republik Indonesia. Jakarta

Mikkelsen, B. (2011). Metode Penelitian Partisipatoris dan Upaya Pemberdayaan: Panduan Bagi Praktisi Lapangan (terjemahan M. Nalle). Yayasan Pustaka Obor Indonesia. Jakarta

Mulyadi, Y. (2016). Kemaritiman, Jalur Rempah dan Warisan Budaya Bahari Nusantara. Talkshow Pekan Budaya Indonesia 2016. Malang

Pradhani, S. I. (2017). Sejarah Hukum Maritim Kerajaan Sriwijaya dan Majapahit dalam Hukum Indonesia Kini. Lembaran Sejarah. 13(2): 186-203

Purnomo, Y. D. H. (2013). Tahun 1511, Lima Ratus Tahun Kemudian. Gramedia Pustaka Utama. Jakarta

Puryono, S. (2016). Mengelola Laut untuk Kesejahteraan Rakyat. Gramedia Pustaka Utama. Jakarta

Riyanto, V.D. (2014). The Miracle of Pride. Elex Media Komputindo. Jakarta:

Ritzer, G. (2012). Sosiologi Ilmu Pengetahuan Berparadigma Ganda (terjemahan Alimandan). RajaGrafindo Persada. Jakarta.

Ritzer, G. dan D.J. Goodman. (2008). Teori Sosiologi dari Teori Sosiologi Klasik sampai Perkembangan Mutakhir Teori Sosial Postmodern (terjemahan Nurhadi). Kreasi Wacana. Jogjakarta

Rompas, R. M. (2011). Membangun Laut, Membangun Kejayaan: Dulu, Kini, dan Masa Depan. Direktorat Jenderal Informasi dan Komunikasi Publik, Kementerian Komunikasi dan Informatika bekerja sama dengan Dewan Kelautan Indonesia. Jakarta

Saenong, M. A. (2013). Pinisi Paduan Teknologi dan Budaya. Ombak. Jogyakarta

Sani, M.Y. (2013). Manusia Kebudayaan dan Pembangunan di Sulawesi Selatan. Dinas Kebudayaan dan Kepariwisataan Provinsi Sulawesi Selatan. Makassar

Simanjuntak, B. A. dam S. Sosrodihardjo. (2014). Metode Penelitian Sosial (edisi revisi). Yayasan Pustaka Obor. Jakarta 
Sukendar, H. (1999). Pustaka Wisata Budaya Perahu Tradisional Nusantara. Proyek Pengembangan Media Direktorat Jenderal Kebudayaan, Departemen Pendidikan dan Kebudayaan. Jakarta

Utomo, B. B. (2008). Belajar dari Dātu Śrīwijaya: Bangkitlah Kembali Bangsa Bahari. Seminar Satu Abad Kebangkitan Nasional. Auditorium Perpustakaan Nasional Republik Indonesia. 27-29 Mei. Jakarta

Wahyu, W. (2017). Kemaritiman Indonesia: Sebuah Kajian Kritis. Jurnal Manajemen Transportasi dan Logistik. 4(2): 211-222

www.invonesia.com/luas-wilayah-negara-indonesia.html diakses 31 Mei 2018

www.kemlu.go.id/id/berita/berita-perwakilan/Pages/Kapal-Pinisi-masuk-dalamdaftar-warisan-budaya-dunia-UNESCO.aspx diakses 1 Juli 2018

Yusuf, A. M. (2014). Metode Penelitian: Kuantitatif, Kualitatif, dan Penelitian Gabungan. PrenadaMedia Grup. Jakarta 